\title{
IV: Tenth International Conference on Penal Abolition: ICOPA X
}

he Tenth International Conference on Penal Abolition (ICOPA X) was
held in Nigeria in August 2002 and broke new ground as the first ICOPA to be hosted by an African nation. Prior to the conference, public awareness and community mobilization were pursued. The goal was to make Nigerians more aware of the penal abolitionist movement and the journey that ICOPA has taken through the years. Public awareness was pursued through a media campaign that involved several local and national television appearances, a nationwide radio program that allowed for call-in discussions, and print media promotions in Nigerian newspapers and one African magazine. In addition, ICOPA X was announced and discussed at many Human Rights Network meetings. ${ }^{29}$ One non-governmental organization, the Nigerian Youth Leadership Movement, led by Ezekiel Ogundare, took interest in the central issues and the ideas surrounding ICOPA and on their own initiative, held a penal abolitionist workshop to raise awareness in their own community in April 2001.

ICOPA $\mathrm{X}$ participants composed a diverse and dynamic group. Participants came from Ghana, the Gambia, Liberia, New Zealand, the United States, Canada, and the United Kingdom. In addition, Nigerians representing the three major tribes and many of the minority tribes from different regions in the country were in attendance. Nigerian participants for ICOPA X included University of Lagos students from the law, psychology, and sociology departments; several representatives from non-governmental human rights organizations; academics; activists; lawyers; high- and lowranking prison officers; high-ranking police officers; the National Human Rights Commission representatives; representatives from the National House of Assembly; ex-prisoners; Nigerian military personnel; poets;

28 The ICOPA movement has travelled the world, starting in Montreal in 1983 and returning several times to Canada over the years. ICOPA was also held in the Netherlands, Poland, the United States, Spain, Costa Rica, and New Zealand before finding its way to Africa.

29 Meetings held the last Friday of every month in the British Council office in Lagos. The purpose of the meetings was to gather human rights activists and nongovernmental organizations in Lagos in order to network and build a community that is organized enough to implement political and social changes. 
musicians; and interested Nigerian youths. The international and continental participants were mainly academics, activists, high-ranking prison officers (from neighbouring West African countries), ex-prisoners, human rights non-governmental organization representatives, and musicians. The local organizing committee was composed of PRAWA staff, student volunteers, and youths from the local community in Lagos. The entire participant list for ICOPA X was approximately 100 people: about 65 University of Lagos students, about 15 international/continental participants, and about 20 Nigerian non-governmental and governmental representatives.

\section{Policy-Makers’ Panel}

ICOPA X was launched in Abuja, the capital of Nigeria, with a policymakers' panel taking place in the Nigerian National Assembly. It was meant to raise awareness about ICOPA and the notion of penal abolition among Nigerian Government officials while bringing forth issues surrounding the death penalty and the need for its abolishment from the criminal code in Nigeria. This panel was scheduled and booked weeks in advance yet there was a slight unexpected problem in scheduling that day: a week before the panel took place, the Nigerian government called a meeting (on the day of the panel) in order to discuss the impeachment of the president of Nigeria on charges of corruption and embezzlement. This resulted in a few hours' delay before the ICOPA panel commenced, during which participants, police, prison headquarters representatives, and academics did not know if the panel would take place at all. The panel did take place; after discussing the impeachment of the president of Nigeria, Nigerian government officials came to ICOPA to learn about penal abolition.

The panel was composed of several members (including the chairperson) from the House of Representatives Committee on Human Rights and Legal Matters, high-ranking police and prison officials, human rights activists, university professors, and representatives from the British high commission.

A debate about the relevance of the death penalty in Nigeria ensued, and a pinnacle was reached when the question of statistics on executions on the country were brought up. I asked when the last time an execution was carried out in the country. ${ }^{30}$ Professor A. Adeyemi ${ }^{31}$ suggested that the

30 I sat on the panel as the PRAWA representative.

31 Dean of Law at the University of Lagos, Nigeria. 
Nigerian Prison Service representatives may be in the best position to answer this question. In response, a representative for the Nigerian Prison Service stated that all over the country State governors refuse to sign execution warrants and that this results in life sentences on Death Row for many prisoners, which inevitably end in the prisoner's death; this form of the death penalty is prolonged and indirect. In response to when the last execution actually took place he stated that "there are a lot of silent executions in Nigeria, as my friend who is present will tell you" and with this he pointed at the police officer sitting beside him. The police officer confirmed that "silent executions" do take place and also confirmed his belief that they are a necessary measure in Nigerian society. These "silent executions" are carried out in police cells, after arrests and prior to court appearances. This debate led to a discussion on deterrence and how ineffective it is. Professor Hal Pepinsky ${ }^{32}$ responded that deterrence in America, with its structured and well-funded criminal justice system, does not work either, and pointed out that the harsher a punishment is the less people relate to it and follow the laws.

Professor Adeyemi gave a detailed presentation on penal policies and African alternatives. He spoke about the researched public opinion of criminal justice in Nigeria and the distrust toward it, resulting in "jungle justice" on many of Nigeria's streets. He defined jungle justice in Nigeria as being comprised of vigilante groups who literally hunt down "armed robbers" and kill them publicly. An issue that arises in these situations, aside from the gross inhumanity of these public and graphic killings, is that tribalism and politics are usually very much in control of such vigilante groups. Professor Adeyemi proceeded to give an in-depth analysis of traditional pre-colonial Nigerian justice and stressed that it did not rely on the death penalty or other violent means of resolving conflicts or dealing with harm, stating that: "It was restorative in terms of social equilibrium; it recognized that you can't solve conflict with conflict, and reconciliation was widely used."

Professor Adeyemi spoke about crime as conflict and thus the solution to crime as encompassed in conflict resolution. He referred to instances where the death penalty was used in African history. He stressed that contrary to

32 Professor of Criminal Justice at Indiana University and one of the international participants at ICOPA X. 
Western opinion, the death penalty in the majority of pre-colonial African societies was used as a last resort, in cases of extreme re-offending and danger to the community; only after banishment was not successful in keeping a community safe were executions implemented. He also noted that executions were used when the crime could not be dealt with "rationally" (i.e., accusations entailing the misuse of witchcraft). After providing more details on historical and contemporary issues of justice, he ended by urging that "it is high time that we come back to embracing traditional justice."

Comments were made by the representative of the Nigerian Prison Service related to "root causes of crime." He spoke about the social problems that criminalize people on a national scale and the Nigerian society on an international scale. He pointed out that capital sentences increase crime in the large divisions they cause by marginalizing, stereotyping, and demonizing entire populations of people: the prisoners he works with every day are one of the most socially feared populations in the country. He stated the panel needs to talk less about those stereotypes and more about alternatives and abolition. In response, the police officer on the panel spoke about the fact that mediation as an alternative to penality is easier among homogeneous populations and he felt that Nigeria has what he called the "stranger element" with the hundreds of different tribes and languages that exist. He spoke about the churches and the mosques and the chiefs "interfering" in the justice process and initiating out-of-court settlements. He complained about victims who want compensation for the crimes they have suffered and expect the police to provide such compensation. $\mathrm{He}$ continued to stress the need for "deterrence" in light of the high rates of violence in Nigeria, specifically associated to the trafficking of women and children, and violence associated with armed robberies. He stressed that long terms of imprisonment will not benefit as an alternative to the death penalty in Nigeria, because unlike Western nations, the criminal justice system's budget is not vast. These budget restrictions are clear when one assesses the court system and finds that 62.4 percent of the prison population has never been to court and may wait an indefinite number of years before being taken to court or getting legal representation.

Discussions were rounded up with comments from the Honourable Ibrahim Zailani of the House of Representatives. He stated that "while Nigeria may not be ready to abolish the death penalty, this panel has made 
it clear that [more culturally and socially appropriate] alternatives need to be put in place of the penal system in Nigeria." He asked that PRAWA and ICOPA X help in putting together a committee that will assist the House of Representatives in drafting legislation to put before the House promoting the implementation and recognition of alternatives to imprisonment and penality. Contact information was exchanged and communication has started in forming this committee and drafting the legislation.

\section{Black Heritage Festival}

From August 24-29, 2002, ICOPAX was hosted by PRAWA at the University of Lagos. On Saturday, August 24, ICOPA participants attended the Black Heritage Festival held at CMS, on Lagos Island. The Black Heritage festival is an annual event held in Nigeria in memory of the oppressive history of slavery and colonization while re-enforcing black pride, promoting peace in Africa, and remembering that abolition of such oppressive forces is possible and that the African people have survived massive atrocities. The opening ceremonies of this event were held at the Race Course Stadium: a large and expensive stadium built by the British colonial government meant for horse racing, a sport that is not popular in Nigeria; the stadium has never been used for horse racing. It was later used as the venue for the independence ceremony from the British when occupied colonial rule was abolished in Nigeria. The opening ceremonies attended by ICOPA X participants included a celebration of the abolition of institutionalized slave trading of West Africans. Dances and festive costumes from all over the country paraded before the public and the Oba (King) of Lagos Island.

\section{Dr. RUTH Morris}

The second day for ICOPA X, Sunday, August 25, was dedicated to the memory of Dr. Ruth Morris. She was a Canadian/American, Prison/Peace Quaker activist, and one of the original organizers of ICOPA I, held in Montreal in 1983. Ruth was a volunteer in her children's schools and began to visit prisons through a Quaker program. She also began to bail men out while they were awaiting trial and taking them into her home for shelter and support. Through her life, she advocated for the rights of the some of the most stigmatized prisoners and ex-prisoners in society. Ruth had been 
a leading international theorist of what she called "transformative justice." She became the author of many books and information pamphlets in the area of penal abolition and transformative justice. Ruth led the organization of ICOPA IX in Toronto in May 2000 and, sadly, she died in September 2001.

A church service in her memory was organized at Yaba Glory Worship Centre. Following were visits to the Kirikiri medium and maximum security prisons where ICOPA X participants shared meals and music in solidarity with prisoners. About 1000 prisoners ate and sang with ICOPA $X$ participants that day. In the evening, a candlelight vigil was held at the Lagoon Front in memory of Ruth Morris. People gathered with lit candles and spoke about her life and her work. Songs were shared after a moment of silence in her memory.

\section{Opening DaY}

The official ICOPA X opening ceremony was held on Monday, August 26 at the University of Lagos Conference Centre. It was followed by presentations by Professor Julia Sudbury ${ }^{33}$ from the United Kingdom and working in the United States highlighting the racist and economic elements of the United States justice system, while emphasizing the importance of an international abolitionist movement that will work in unity to abolish the atrocities occurring through penal systems around the globe. Justice S.A. Brobbey from the Court of Appeal in Ghana ended with a presentation about human rights issues in relation to the criminal justice system's failures in West Africa. The theme was established early: that the penal system is malfunctioning around the globe and that alternatives to it are desperately needed.

Presentations throughout the conference included an assessment of the psychological consequences of torture, the implementation of transformative, and community justice programs around the globe, and resistance movements' successes and obstacles. A powerful moment during one of the sessions included an American presenter, Chino Hardin with the

33 Professor in the Ethnic Studies Department at Mills University, California and one of the international participants at ICOPA X. 
Prison Moratorium Project in New York. She discussed the problems with the American justice system and narrated personal experiences from her time in American youth jails. This session was great in challenging the general stereotypes of "crime" and "criminals" that abide in Nigerian society. Chino Hardin spoke about her years as a member of a street gang and the armed robberies she was involved with. In Nigeria, armed robbers are feared more than any other "category" of people and are viewed as the most dangerous threat to social safety. The Nigerian participants' reaction to Chino (with whom they had spent time prior to this session) was one that was openminded and, upon seeing her accomplishments, hearing about her hardships in American prisons, and hearing her articulate battle for abolition, many later stated that their stereotypes were greatly challenged.

\section{Alternative Models}

Tuesday, August $27^{\text {th }}$ was dedicated to a focus on alternative models to the penal system, both in theory and in practice. Traditional models of justice were presented and discussed in detail, with Professor Oko Elechi outlining the historical aspects of general African indigenous justice systems and the links the majority of them had to transformative justice ideology. He stressed that most contemporary justice systems are Euromale centred and are not natural to African societies in general. This was accentuated with presentations about the Maori struggle in New Zealand and the inappropriateness of the colonial justice system in dealing with nonEuropean community conflicts.

These criticisms were followed by a plenary focusing on practical alternatives to the penal system. The peacemaking perspective was explored and accentuated with presentations by members of the Alternatives to Violence Project (AVP) in Nigeria and their work with the International Committee of the Red Cross (ICRC). The AVP presentation focused on the Nigerian situation and the role of conflict resolution within the context of communal (sometimes tribal) conflicts. Mr. Chiemeka, on behalf of AVP, emphasized the fact that violence is inevitable in every society and that the key to violence is the chosen approach in resolving it. He gave an analysis of what he called the chaotic Nigerian society and said that how a society chooses to manage its conflict is what constitutes its civilization. He gave examples of Nigeria-specific issues that have lead to violence and demonstrated how AVP resolved such conflicts non-violently. His 
presentation was complemented by Ellen Flanders from the United States, who is one of the founders of AVP. She shared some of her experiences with AVP and presented examples of how AVP has transcended violence in many parts of the world.

PRAWA employees participated in ICOPA $X$ not only through organizational efforts, but also in paper presentations. In a paper entitled "Alternative to Imprisonment Measures: Lessons from Africa," Saib Feyisetan ${ }^{34}$ presented on behalf of Chukwuma Ume. ${ }^{35}$ This highlighted some parts of the Nigerian constitution that relate to prison and punishment and the international laws that guide the treatment of prisoners. He also spoke about the links between present day African prisons and colonization. He emphasized the fact that alternatives to imprisonment are not foreign or new concepts in Africa, but rather that they are a part of the heritage and history of the continent. He gave examples of successful implementation of alternatives to imprisonment in Zimbabwe, Kenya, and Nigeria.

Mr. Moses Blokanjay Jackson ${ }^{36}$ spoke about the immediate need for alternatives to the penal system in Liberia. He belongs to an organization called Volunteers for the Care of Abused and Abandoned Children and presented a contextual account of the war in Liberia and national and international governmental links to the conflicts that exist there. He spoke about the power and economic imbalances in Liberia and highlighted the fact that war measures being sanctioned are only furthering the wealth of the rich while driving the poor further into poverty. He explained that the situation in Liberia, promoted by political and economic motives, forces the poor to survive only by relying heavily on the rich. He gave a diverse set of examples to support these statements, from the exploited exportation of diamonds industry to the forced prostitution of women and children in Liberia. Within such a context, he stated that a justice system promoted by the State (those in power and in control of the nation's wealth) is not only dangerous, but is also futile. With this sort of context and with a better understanding of this history of the conflicts in Liberia, it became clear that a colonial penal system is not only ineffective due to the current war, but will continue to be inappropriate after the war is subdued.

\footnotetext{
PRAWA employee: Head of the Communications and Media Department. PRAWA employee: Prison Officers Human Rights Training Program.

One of the continental participants at ICOPA: a human rights activist in Liberia, Moses spoke frequently about the civil war his country is experiencing.
} 
Highlighting the West African transformative justice context, Justice Brobbey from Ghana spoke about the implementation and successful functioning of the Victim Offender Mediation Model in Ghana. He started his presentation by stating that there are two recognized justice systems in Ghana: those that are formal (run by the State) and those that are informal (run by the community). He said that people oftentimes resort to the informal sector of jurisdiction mainly due to convenience, accessibility, time, and financial restraints. He highlighted the formal system's restrictions through the court processes and the flexibility of the informal system through arbitration/mediation. He gave details of the formal justice system in Ghana and contrasted it to the informal processes that the majority of the people pursue.

Dr. Senghor Aboubakar from the Gambia presented a paper on behalf of Hanna Foster of the African Centre for Democracy and Human Rights, on the Victim-Offender Mediation model being implemented in the Gambia. He spoke about the community's open response to it. He stated that the Gambia is a small country of about 1.4 million people, and because of that, the number of people in prison is relatively small. He pointed out that going to court or the police in the Gambia is seen as taboo because people simply cannot embrace the idea. He spoke about the African Centre for Democracy and Human Rights' mediation services and stated it has been used in resolving many forms of conflicts ranging from individual conflict within the home to larger scale conflicts at the macro-societal level.

It was noted that ironically, the majority of justice projects in Africa are funded by European donors. It is interesting to note that prior to European funds, African justice models continued to exist throughout the continent during colonization and continue to be found in contemporary "post"colonial time. It is also key to note that European funds aid in formalizing African justice models and this creates a danger of co-optation, opening colonial avenues for the creation of a more systemized and inflexible model that may mirror the existing malfunctioning and culturally inappropriate criminal justice systems in Africa.

\section{Exposing OpPression through Musical Expression}

On the evening of August $27^{\text {th }}$, ICOPAX participants went to the New Afrika Shrine in Ikeja, Lagos, for a special concert by Femi Anikulapo Kuti entitled 
Exposing Oppression through Musical Expression. Femi Kuti is the son of the late musician/activist Fela Anikulapo Kuti. Fela Kuti's legend in Nigeria and Africa is one that exhibits the oppression and inhumanity of colonization and the ensuing military regimes in Nigeria. Fela's mother was murdered by the Head of the Military State at the time, Olusegun Obasanjo. Ironically, Obasanjo is the present day "democratic president" of Nigeria. During his life, Fela was imprisoned several times for his outspoken opposition to military rule. Femi grew up watching the police arrest and beat his father. Fela's original Afrika shrine was destroyed twice by the government. Femi Kuti performed for ICOPA X participants as well as the Nigerian public for whom he made admission to the shrine free and open to all for the night. The African drums, dances, and instrumentals were also accompanied by Femi's speeches on the history of Nigeria's oppressive states and the present day hardships and exploitations that the general population lives in directly due to corporate and state embezzlement of Nigeria's resources and the unequal distribution of wealth. ICOPA X participants danced, sang, and listened to Femi Kuti's saxophone, his band's accompanying instrumentals, and enjoyed the true African hospitality of one of Nigeria's leading musicians.

\section{Abolition of Slavery}

Wednesday, August $28^{\text {th }}$ was dedicated to remembering the abolition of slavery in West Africa in its pre-colonial state. About one hundred ICOPA $\mathrm{X}$ participants went to the National Museum in Onikan, Lagos, and saw ancient African artefacts. It was noticed that many of the most precious artefacts, such as the Benin Bronzes and several ivory masks, had to be represented by present day replicas due to the fact that the originals, without the consent of Nigerian authorities, are being held in British museums for what is called "proper preservation" of the monuments. Also in the museum was a visual display of past military and present "democratic" rulers. On display was the car in which Murutala Mohamed was assassinated. He was the head of state of Nigeria who preceded Obsanjo's military rule (1979) and his assassination was followed by numerous military coups. The car was in a room surrounded by pictures of past military dictators and their governors/generals.

After the museum, the participants travelled to Badagary, a small town on the outskirts of Lagos State. It is located on shores where slave trading 
took place. Visits in Badagary included one of the gravesites of the African chiefs who traded slaves to Europeans. Near his grave the shackles he used to capture and enslave people were on display. Participants walked from his grave to the Gate of No Return that marked the spot where boats loaded for departure to the Americas and Europe. Across the street from the bronze gate with sculptures of white men whipping West Africans who had been stripped and shackled was the Brazilian Baracoons. These Baracoons consisted of forty slave cells that were used to hold people as they waited for ships to depart. All but two of the cells have been converted into residential homes for the descendants of the chief of that village who was collaborating with Europeans and North/South Americans in the selling of West Africans. Inside this compound participants visited the men's and the women's cells. Upon learning that forty people were held in each cell, forty participants comprising mainly of students and several international participants piled in and closed the small wooden doors. The space was very tight and air was restricted. On the way out of the cell was a picture of the chief who owned the cells and the gifts and clothes he was given in return for slaves. These included glass plates and one cup, velvet robes, and a wooden trunk. The atmosphere was tense as participants confronted the realities of historical oppression physically and emotionally.

The evening featured poetry readings by Dr. Tony Marino, a medical doctor, published poet, and human rights activist in Ibadan, Nigeria. Poems were also read by some Nigerian youths, and music was played by several international and national participants. After the poetry reading, Dr. Marino donated books for prisoners in Lagos State. An overwhelming and emotional day ended with a sense of sadness but a glimmer of hope in notions of resistance and solidarity beyond prison walls.

\section{Financial Context of the Criminal Justice System}

The last day of ICOPA $X$ focused on the economic and financial context of conflict and the criminal justice system. Mr. Gerald Onwusi, a human rights lawyer in Nigeria, presented a detailed assessment of the oil conflicts in Nigeria's delta region. He spoke about the late political activist Ken Saro-Wiwa and the many others who have lost their lives in an attempt to protect their communities and families from the adverse effects of oil exploitation. He spoke about the people who hide behind company names 
to commit crimes upon the community and stated the need for civil justice to intervene and sue those involved so as to ensure they face consequences for their misdeeds. In his paper, he suggested that communities that are affected should be compensated. He mentioned an example of what the American companies have come to call the "super-fund" that is said to be created for the purpose of paying compensation to the people of Nigerian oil communities. Unfortunately, Mr. Onwusi did not highlight the fact that these funds are never sufficient in the face of the damage done to the communities and to the environment and only serve as short-term solutions to longterm problems of exploitation, environmental damage, and community breakdown. He concluded by stating that people should know their rights and exercise them through such compensation schemes, emphasizing the need to rely on the criminal justice system to secure financial compensation for oil related conflicts in Nigeria.

His presentation was followed by a presentation that came in direct contradiction with his conclusions. Mrs. Jane Hemesson, retired Commandant of the Prison Training School, retired State Controller of prisons, and present Deputy Director of PRAWA, spoke about the financial context of the criminal justice system in Nigeria. She spoke about the large sums of money being spent on the maintenance of prisons in Nigeria and mentioned eleven new prisons being built in the country. She supported penal abolitionism and stressed the counterproductive financial element of a justice system that does not serve the Nigerian people. She made reference to the country's massive natural resources and wealth and stated that growing budgets of both the prisons and the police in Nigeria have begun to present a drain on the national budget and was in need of direct and immediate reexamination.

\section{Voices from Prison}

Conference presentations were concluded with a session focusing on the brutalities of imprisonment and included presentations from prisoners (whose papers were presented by ex-prisoners or close friends on their behalf) and ex-prisoners. The first presentation was written by Tiyo Attalah Salah El who is presently serving a life sentence in an American prison. His paper was presented by Professor Hal Pepinsky and included details of the injustices implemented by the American penal system in relation within the 
context of power imbalances related to class, race, and gender. He spoke about the indefensibility of the penal system and addressed issues related to the inadequacy and inappropriateness of reform when faced with the inhumane and oppressive penal structure. Clever Akporherhe and Felix Obi spoke about their experiences in Nigerian prisons and Faith Nolan presented a paper on behalf of Osa who was still in prison at the time.

Sam Edokwa also presented a paper during this session. He is an exprisoner who is a soldier with the Nigerian Army. He was arrested in 1996 on a civilian matter, picked up by the police and, without evidence against him, put in prison. He was held in prison as an awaiting trial prisoner for three years and, in the end, was never convicted. His speech was short due to the fact that military personnel came with him for the presentation. $\mathrm{He}$ was in full military uniform during his speech and, despite the presence of his military superiors, did manage to emphasize the lack of implementation of the United Nations human rights standards for the treatment of prisoners in Nigerian prisons. He had to take official time off work to present at ICOPA, hence the military uniform and escorts, and despite this, gave an accurate presentation of his time as a prisoner and his contact with the police force. Before and after his presentation, during times when he was not in uniform and not escorted by military personnel, he got heavily involved in abolitionist discussions, promoting the ideology and advocating for an implementation of alternatives to the system that are separate from the penal structure and not within state control. His presence at ICOPA X was valuable and represented a great deal of resistance to many oppressive forces.

\section{The Discussion Continues}

Throughout the conference, there were many intense discussions among the participants. Many of the Nigerian students in attendance expressed concern about the nonchalant attitude of Nigerian lawyers and judges toward the suffering of prisoners. The stories shared by (ex)prisoners and the justifications for inhumanity presented by several criminal justice practitioners (mainly laying bureaucratic blame for system malfunctions on criminal justice branches they were not working for) prompted discussions among participants in between presentations and over lunch breaks. One of the Nigerian lawyers present reacted by telling a large group of students 
that "Nigeria has just entered into democracy after thirty years of military dictatorship" and thus their expectations for their nation's development were premature and set "too high." This was ensued by a heated debate on the politics of injustice. It seemed that this, among many other times throughout ICOPA X, a small minority of those who were employed by the criminal justice system were challenged or threatened by the criticisms and facts being presented. It also seemed that the more students heard, the more disturbed they were by the injustices occurring in and through the Nigerian criminal "justice" system. While many did not trust the system or the state, they found that the details presented still shocked them. It seemed like the new generation of young adults often came in conflict with a minority of the old generation of criminal justice practitioners and at times, some of the older generations of activists and academics. This made for some really interactive sessions and debates. ICOPA $X$ days and nights were packed with a lot of loud, heated, and, at times, hostile, discussions. These discussions did not break up the group dynamic; in fact, those who disagreed chose to spend more time in discussion despite recognizing the existence of possibly irreconcilable differences.

The stories shared were intense and, at times, violent. Conflict, it seems, is inevitable. True solidarity occurs with the implementation of a respected diversity, an understanding that differences are not only acceptable, but essential for the human social condition. And within the spirit of such diversity lies the understanding that institutions and "systems" of control are too frigid, and thus structurally too oppressive in their interactions with a flexible and diverse society. For disempowered populations, these oppressions are a reality, they are all encompassing, and they are devastating. For those who are privileged, who are empowered, who do have opportunities to speak out, and to create opportunities for change, it is not a choice, but a responsibility. It is a responsibility that the current human condition demands, that the current global order needs, and that the disempowered, oppressed, and silenced populations are, at times, forced to rely upon.

ICOPA $X$ was a powerful experience, emphasizing to me that the path to peace and equality is not quiet; it is full of stories of brutality and it is packed with disagreements. When the people repossess the power to define and resolve their own conflicts, they are bound to "disagree," and that disagreement is essential. I have come to understand that silence is a tool of 
oppression. Speaking out is a tool of resistance. Some speak through song, some speak through stories, some speak through writing, ${ }^{37}$ some speak through research, and some speak through actions. ICOPA X spoke loudly in West Africa those few days.

This issue of the Journal of Prisoners on Prisons works toward raising awareness, not to demonize or criticize Nigeria, but to expose and criticize a penal system that is man-handling too many people all over the world. I hope that those who read it are able to transcend their stereotypes about Africa and see that these stories and experiences of people in Nigerian prisons are not a reflection of Nigeria, but are a reflection and accurate representation of the penal system's goals, structures, behaviours, and institutional brutalities.

37 The Journal of Prisoners on Prisons presents this opportunity to prisoners all over the world. 